\title{
PROJECT MANAGER SKILLS, RISK MANAGEMENT TOOLS
}

\author{
Vlăduț Severian Iacob \\ Ștefan cel Mare University \\ severianvladutiacob@yahoo.com
}

\begin{abstract}
Although the projects are different from each other there are many common things that contribute to their success. Looked overall, the success of a project is the result of a multitude of factors. This person is considered the "engine" of the project. The man who makes the action set for the achievement of project objectives to be brought to an end. The project manager must have the technical knowledge and economic diverse. He should be able to choose a team and lead. You must be tenacious, combative, to know how to communicate both within the team and beyond. In a word, the project manager must have an impressive stock of knowledge, skills and abilities and appreciate as Peter Drucker, to "exist for the organization. To be its servant. Any management who forget this will only cause damage to the organization. "This study will focus on highlighting the skills of the project manager and their role in managing difficult situations or risk.
\end{abstract}

\section{Keywords}

project manager skills; risk management; project; knowledge; abilities; difficult situations

\section{JEL Classification}

M10

\section{Introduction}

The success of a project manager is mainly related to abilities and skills that he has, whether some are native or otherwise acquired during periods of practical training or personal experience. Shaping the personality of such a leader is a process of continuous accumulation, knowing that there is no individual who hold the full set of theoretical and practical information necessary to carry some specific tasks.

The presentation of these issues is not mandatory in new things. These findings are the result of multiple proven times and recorded in various studies by many authors as we shall see later in this document.

The presentation of these skills, according to various authors leads to the recognition of the link between the project manager skills and successfully resolving situations of risk, and of course, the success of the project.

\section{The outline of a successful project}

Human activities and economic entities tend to focus on completing an objective or a group of complementary objectives to cover certain needs of the individuals. Whether it's planning an interior or public space or organize a party, or the systematic construction of a house or road in a locality, or any other actions for the realization of an idea, you can refer to the concept project.

To achieve any of the stated ideas or any other ideas initiators in their approach, will seek financial, material will consume their own or other people's work completion foreshadowing in some time. As such, a project, the actual meaning of the word is an "action taken to achieve a thing without the guarantee of success" (NODEX, 2002). 
In connection with the term "project", but mostly with the project management literature many authors agree (Rutman \& Mowbray, 1983; Conrad \&Hedin, 1987; Valadez \& Bamberger, 1991; Măţăuan, 1999).

As project management has been thoroughly studied and analyzed in order to improve its continuous the panoply of authors who have shaped the definition of the term has been enriched with other authors (Munns \& Bjeirmi, 1996; Ciobanu, 2002; Turner, \& Simister, 2004; Borgăoanu, 2005; Javid, 2009; Căprescu, 2010; Bulat, 2011; Opran, et al., 2012). Typically, these definitions are referring to "specific elements: objective data specifically allocated resources, planned activities, and dedicated team period (Pascu, 2005).

The successful implementation of a project has different meanings from person to person because each developed different expectations. For example, those who are directly involved in the project see the light of its success in framing budgets, quality and Performance achieved, whereas for those who look outside the project, meaning success usually comes down to assessing the usefulness and progress.

In relation to the success of a project, an interesting statement is made by Morris and Hugh (1986). According to them, the success of a project depends on realistic objectives aiming customer satisfaction and stakeholders, profitability and value of the project.

A reference work presenting the success of projects in a literature review is made by Prabhakar (2008). In addition to this work, to highlight the relationship between project success and project leader skills it is susceptible to bring into question the work of Kerzner (2003). He identified a number of critical factors for successful projects including those related to the project manager, the criteria that have been selected, organizational adaptability, leadership, commitment to planning and control. Based on these assumptions it can shed light on the need to strengthen the relations between the project team, cohesion and collaboration within it, by enhancing management level. Leading a welded team, a leader can easily handle the entire project towards employment in the constraints of time, cost and quality.

Therefore, the presence of the project manager, as an important part in the project (systematic and direct intervention in different phases) entitles him to award the project outcome regardless its success. Therefore, a successful project manager must possess the skills and competencies that enable him to manage and complete the project with professionalism and in a successful way.

\section{Skills and competences of the project manager}

A person cannot be a project manager if not nominated for this position and if there is a project initiated. In these circumstances the project manager appears to be the major resource inputs category along with the rest of the team and of the other types of material, financial. In the position of leader that person "assume responsibility for the planning, implementation and completion of the project," says Meredith \& Mantel (2009), indicating the six areas of competence that must evolve a project manager "team building, organization, communication, leadership, adaptability and technological skills. "

Jawid (2009) delimitation of previous records while representing Katz (1955, 1993) on effective manager skills or qualifications of the individual (human skills), conceptual (conceptual skills) and technical (technical skills). About this short reference will be made below.

Human skills of the manager's ability to work "side by side" with other team members to mobilize and commit-instill and support. This ability is related to adaptability and communication skills. Also included in the category of human prowess can be will, flexibility, patience, persuasion, delegation, balance, realism, dedication, generosity, 
stability, speed-thinking discipline. Conceptual qualification is related to the systemic perception of manager. It would be about how it detects changes in the effects of processes occurring within projects and interdependence of processes. In the conceptual qualifications are included organizational skills (vision, strategy, planning, guidance, coordination, provision, forecasting, etc.). The technical qualifications make the manager able of using knowledge, tools and specialized techniques. Through this type of qualification the manager must demonstrate varied technical knowledge. He also needs to have knowledge about the project in general, to know which are the project phases and the major processes that he leads, to understand the technology. Other technical skills may be related to the use of computers and specialized software programming or tracking activities and control. For this scientific endeavor is interesting to note the entries made by Anderson (1992) in which it accepts the project manager must be able to identify problems and find a good solution to be able to resolve conflicts.

Taking into account the views expressed by the authors cited, as well as those of other authors who have addressed this area and which have been studied in the preparation of this material, it is necessary to agree on the existence of a correspondence between a set of skills and a good project manager. The most common opinion (Mironescu, 2013), refers to the importance of the accumulation of new skills such as communication and decision, planning, organizing, monitoring, control and evaluation team. A second set of items aimed expertise multidisciplinary, giving the manager a broader view of the whole project and able to react quickly in the event of certain disturbances inside or outside their processes.

\section{Project risks and their management}

The existence of individuals and of any activity is accompanied by inherent risks that take particular forms depending on the size, type and conduct. Effects of these risks are direct and powerful are reflected upon these activities. Although the risk is not perceived to be destructive the events classified as generally risk are adverse. They cannot be totally eliminated, but the establishment and enforcement of measures can reduce more within any organization and / or project it is natural to make substantial efforts to identify sources of risk and to establish procedures to allow keeping risks under control. It is the prerogative of risk management discipline that has developed rapidly in recent years, both at conceptual, theoretical and practical level. Failure to give due importance to the effects of risks could lead to material financial loss record and unfortunately human.

The evolution of today's society makes possible use of the information technology risk management enabling decision makers to have real-time information and to obtain a minimization of the negative effects of risk.

Existence of a risk has a positive effect, i.e. to generate progress. Thus, by stating that "a higher risk may lead to a higher gain" Opran (2012), brings into question the fact that successful organizational structures that structure their work can invest in projects with higher certainty in market conditions unpredictable precisely why they have the ability to assess and minimize risks. In the projects, as in any organization, the risks may be internal or external.

Generally internal risks are relatively easier to manage. Some of these are related to the ambiguity of objectives and priorities, the incoherence of the specifications and documentation, the imprecision of defining specific responsibilities or activities within the project. Others refer to the technical and technological risks, i.e. the differences between old technologies and new discoveries that benefit from the lack of training and vision in the uptake and application of information technology innovations. An important place in the category of internal risks is those related to 
human resources. Primarily the discussion is about the education of persons involved in project and one can talk about mindset, competence / incompetence, abuse of power, qualification / disqualification. Mismanagement of logistics (communication inside and outside), material and financial resources (price risk, currency risk, etc.) can put the organization in the face of other internal risks.

Compared to internal risks, external ones are not so easy to manage as a result of political actions (changes of regimes / governance, lack of coherent strategy), economic (crisis, embargoes, allocations of GDP) legal (common legislative changes), environmental (climatic conditions: extreme heat, cold, earthquakes, floods), regulatory (authorizations, remittances) Community (interruption in the supply of services: water, heat), social (social movements).

The success of a project means to overcome any difficult situations or risks during this phase. Responsibility of good finalization falls in account of risk management defined by Barsan \& Smith (2003) "the systematic identification, analysis and response to the potential risk of a project." In the agreement with them is Stan (2005) as well as Opran (2012), which consider risk management as a way "to manage uncertain events success." Taking these ideas Iacob (2013), presents the risk management as a "structured and formal approach, focused on the necessary steps and actions planned to determine and control the risks, keeping them to an acceptable level." As a continuous process of planning, risk management will help the project manager to overcome the adverse events and maximize those of positive events. It is especially effective as the earlier triggers, as close to the initiation of the project.

In risk management, claims Opran (2012), four principles must be observed: a) a project cannot accept risks unrelated to the project, b) decisions on the risks must be taken at the appropriate levels, c) accept risks when earnings are higher than costs d) project risk management is integrated into the general project management process.

To be effective in risk management proceed primarily to assessment of risk (risk factors are sought) followed by design and planning responses (their priority is building a hierarchy and response strategy). Implementation of such a strategy is followed by a systematic monitoring risk within the department. Such a component is specific to the general organizational structure of firms being led by a risk manager.

\section{Risk Manager and his attitudes}

Because there is no organization / project that does not face a risk, those who are in a position to coordinate such a project might differ in their opinions of risk depending on education, their culture, personality development. Whilst having as support such an argument, Opran (2012) argues that attitudes towards risk as well as its perception by individuals, is dependent on variable factors such as emotions, the presentation of reality, humor, etc.

It is appropriate that the risk manager has a multidisciplinary training, as well as a varied experience and to be in trend with the developments of the project activity. He must have a strategic vision of how to fight and / or risk mitigation. Where there is no specialized department or specialist employee for such activity, the risk management is the responsibility of the general manager of the company / project. Studies performed by different authors on managerial behavior, allowed the construction of patterns in the approach to risk. In this context there are leaders who avoid taking responsibility by delegating team members and third parties. There are managers who appreciate the risks as controllable elements, aspect they do not take into account the potential uncertainty and therefore assumes no responsibility.

It is interesting to discuss this and other types of managerial attitudes, which, accordingly to some of cited authors, are considered unconventional classical theory of risk: low credibility in probabilistic estimates the importance of managerial 
preferences differentiated risk taking and risk taking by managers. By assuming the managerial decisions, there are highlighted several aspects to consider in: its own personality, confidence in the importance of probabilistic estimates, assuming responsibility for risk.

\section{Conclusions}

Completion of this study will familiarize readers with some concepts of project, risk and managerial skills. However, the purpose of the work was to demonstrate that there is an intense connection between skills and competencies of a project manager in risk management. Assuming risks and the use of modern theories on the managerial decision-making is basically the key to success of any project, but for this, the most important resource of the project - the manager - must acquire various skills and competencies and experience.

\section{References}

Anderson, S. D. (1992), Project Quality and Project Managers, International Journal of Project Management, Elsevier.

Bârsan, N., Popescu, I. (2003), Managementul riscului. Concepte, Metode, Aplicații, Editura Universităţii „Transilvania” din Braşov, available on http://file.ucdc.ro/cursuri/F_2_M41_Modelarea_deciziei_economice_Barsan_ Pipu_Nicolae.pdf.

Bulat, V. (2011), Cum scriu un proiect? Ghid de reguli de bază de scriere a unui proiect, Chișinău, available on www.serviciilocale.md/download.php?file.

Borgăoanu, A. (2005), Managementul Proiectelor, Bucureşti, Editura Economica.

Căprescu, M. (2010), Teoria Curricumului, available on http://www.svedu.ro/curs/tc/c9.html

Ciobanu, R.M. (2002), Managementul proiectelor, Iaşi, Ed. Gh. Asachi.

Conrad, D. Hedin, D. (1987), Youth Service: A Guidebook for Developing and Operating Effective Programs, Washington, DC: Independent Sector.

Farcaș, E. (2010), Orice firma are nevoie de un manager de proiect, available on http://www.romanialibera.ro/bani-afaceri/angajari/orice-firma-are-nevoie-deun-manager-de-proiect-206780.html.

Fundația FIMAN, (1993), Managementul proiectelor în ţările în curs de dezvoltare, Bucureşti, Ed. ALL.

Iacob, V.S. (2013), Strategii de promovare a proiectelor europene, Note de curs USV. available on seap.usv.ro.

Javid A.S. (2009), Project manager skills necessary for Project success, available on available on http://faculty.kfupm.edu.sa/CEM/soliman/CEM520/CEM520SamplePresentationsofStudentspapers/CEM520TermpaperPresentattionJavid.p df.

Katz, L.R. (1955), Skills of an Effective Administrator, Harvard Business Review, available on http://www.studymode.com/essays/Robert-Katz-Skills-Of-AnEffective-1007858.html

Katz, L.R. (1993), Skills of an Effective Administrator, Harvard Business School Press.

Kerzner, H. (2003), Project Management: A Systems Approach to Planning, Scheduling, and Controlling, available on http://bookos.org/g/ Harold\%20Kerzner,

Măţăuan, G. (1999), Evaluarea programelor sociale, Ed. Expert. 
Meredith J.R. \& Mantel, J.S. (2009), Project Manager, a Managerial Approach, John Wiley \& Sons, Inc, available on http://allearth.files.wordpress.com /2012/06/mobook9377.pdf

Mironescu, R. (2013), Elemente fundamentale de management, Editura Alma Mater, Vasile Alecsandri University, Bacau.

Morris, P.W.G., Hugh, G.H. (1986), Preconditions of Success and Failure in Major Projects Templeton College, the Oxford Centre for Management Studies, Kinnington Oxford, Technical paper No. 3.

Munns A. K., Bjeirmi, B.F. (1996), The role of project management in achieving project success" International Journal of Project Management, Elsevier Science, 14(2).

Opran, C., Stan, S., Spânu, P. (2012), Managementul riscului în proiectele europene, Bucureşti, available on comunicare.ro/cursuri/u3/Managementul Proiectelor. pdf.

Pascu, R.V. (2005), Introducere în managentul proiectelor. Sibiu, available on ccimn.ulbsibiu.ro/.../carti/introducere_in_managementul_proiectelor.pdf.

Prabhakar, P. (2008) What is Project Success: A Literature Review, International Journal of Business and Management, September, 3(9).

Rutman, L., Mowbray G. (1983), Understanding Program Evaluation, Beverly Hiss/London/New Delhi: Sage Publications.

Turner, J.R., Simister, S.J. (2004), Manual Gower de management de proiect, Editura Codecs.

Valadez, J.J., Bamberger, M. (1994), Monitoring and Evaluating Social Programs in Developing Countries, Washington, D.C., EDI of the World Bank, available on http://www.pol.ulaval.ca/perfeval/upload/publication_192.pdf. 